\title{
Reading Robert and beyond: Narrative analysis of the story of a sexually abused Catholic man
}

\begin{tabular}{|c|c|}
\hline \multicolumn{2}{|c|}{$\begin{array}{l}\text { Authors: } \\
\text { R. Ruard Ganzevoort }{ }^{1,2} \\
\text { Jean-Guy Nadeau }\end{array}$} \\
\hline \multicolumn{2}{|c|}{ 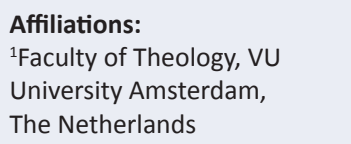 } \\
\hline \multicolumn{2}{|c|}{$\begin{array}{l}{ }^{2} \text { Department of Practical } \\
\text { Theology, University of } \\
\text { Pretoria, South Africa }\end{array}$} \\
\hline \multicolumn{2}{|c|}{$\begin{array}{l}{ }^{3} \text { Faculté de théologie et } \\
\text { de sciences religieuses, } \\
\text { Université de Montréal, } \\
\text { Canada }\end{array}$} \\
\hline \multicolumn{2}{|c|}{$\begin{array}{l}\text { Correspondence to: } \\
\text { Ruard Ganzevoort }\end{array}$} \\
\hline \multicolumn{2}{|c|}{$\begin{array}{l}\text { Email: } \\
\text { r.r.ganzevoort@vu.nl }\end{array}$} \\
\hline \multicolumn{2}{|c|}{$\begin{array}{l}\text { Postal address: } \\
11 \text { Admiraal van Gentstraat, } \\
3572 \text { XE Utrecht, } \\
\text { Netherlands }\end{array}$} \\
\hline \multicolumn{2}{|c|}{$\begin{array}{l}\text { Dates: } \\
\text { Received: } 20 \text { May } 2013 \\
\text { Accepted: } 22 \text { July } 2013 \\
\text { Published: } 06 \text { Aug. } 2014\end{array}$} \\
\hline \multicolumn{2}{|c|}{$\begin{array}{l}\text { How to cite this article: } \\
\text { Ganzevoort, R.R. \& Nadeau, } \\
\text { J.-G., 2014, 'Reading Robert } \\
\text { and beyond: Narrative } \\
\text { analysis of the story of a } \\
\text { sexually abused Catholic } \\
\text { man', Verbum et Ecclesia } \\
\text { 35(2), Art. \#868, } 8 \text { pages. } \\
\text { http://dx.doi.org/10.4102/ } \\
\text { ve.v35i2.868 }\end{array}$} \\
\hline \multicolumn{2}{|c|}{$\begin{array}{l}\text { Note: } \\
\text { This article is part of a } \\
\text { research funded by the Social } \\
\text { Sciences and Humanities } \\
\text { Research Council of Canada. }\end{array}$} \\
\hline $\begin{array}{l}\text { Professor Ruar } \\
\text { is a research a } \\
\text { Professor Joha } \\
\text { the Departme } \\
\text { Theology at th } \\
\text { Pretoria. }\end{array}$ & $\begin{array}{l}\text { d Ganzevoort } \\
\text { sociate of } \\
\text { nn Meylahn in } \\
\text { t of Practical } \\
\text { e University of }\end{array}$ \\
\hline Read online: & \\
\hline 口ifipa & $\begin{array}{l}\text { Scan this QR } \\
\text { code with your } \\
\text { smart phone or } \\
\text { mobile device } \\
\text { to read online. }\end{array}$ \\
\hline
\end{tabular}

This article seeks to contribute to the understanding of what is at stake in counselling religious male victims of sexual abuse. We analyse the narrative of 'Robert', a sexually abused Roman Catholic man who later committed suicide. We focus on issues that concern many sexually abused males, such as talking and relationships, agency and responsibility, emotions of guilt, shame and anger, sexual identity, God-talk and God-images. In terms of a triangulating case study, we then confront this narrative analysis with some biographical elements gathered from other sources, from which we complement and critique the analysis.

\section{Introduction}

Sexual abuse and its effects on masculine spirituality is a topic that has received little attention despite some recent interest. It is only in the past decade or so that more attention has been devoted to the $4 \%-10 \%$ of men that suffer sexual abuse (Mendel 1995). Systematic research into the spiritual dimension is still very sparse (Ganzevoort 2002, 2006). There are indications that sexual abuse may lead to identity questions, a decrease in religious engagement and impaired overall functioning, but also spiritual growth. The story of Robert (sexually abused Roman Catholic man) (pseudonym) shows signs of all four.

The relationship between the interviewer and Robert, although part of a research project (Nadeau, Golding \& Rochon 2012), was embedded in a community setting ${ }^{1}$. They knew each other before the interview and continued to have some contact until Robert committed suicide whilst facing allegations of sexual misconduct. This wider context of the interview narrative cannot be left out of the analysis, as we will show in the last section.

The central aim of our article is to understand the ways in which Robert made sense of his life experiences, including sexual abuse and his religious upbringing, his spiritual experiences, and his relationships with their social and religious context. These narrative constructions are linked referentially to the objective 'facts' of a person's life and performatively to the audience the narrator wishes to address. The obvious tension between these two dimensions is often neglected in narrative research. An intriguing aspect of the case of Robert lies precisely in the fact that we were exposed to additional and complicating information about his life and experiences. This article then offers not only a narrative analysis of a particular case, but also a critical perspective from where we can start to discuss the merits and limits of narrative research.

We will first present some biographical elements. Then we will briefly describe our approach to narrative analysis. The analysis itself centres around five issues, the first four brought up by Robert and the last one by the interviewer, based on the research questions. The five issues are: (1) talking and relationships, (2) agency and responsibility, (3) emotions of guilt, shame and anger, (4) sexual abuse and homosexuality and (5) God-talk and God-images. We then confront this narrative analysis with some biographical elements gathered from other sources, to complement and critique the analyses.

\section{Encountering Robert}

The narrative portrays Robert as a homosexual Canadian man in his forties. He was born into a very religious family of seven children, where he received a traditional Catholic education including religious schools and Sunday masses.

Between the ages of 13 and 16, Robert was victimised sexually by a friend of the family, approximately once a week. The perpetrator, a married man, was highly active in sports and youth work. Robert describes him as: 'A man with a strong personality. He had big hands. He 1.The interview was conducted by Mrs Carole Golding, a research student with the second author.

Copyright: @ 2014. The Authors. Licensee: AOSIS OpenJournals. This work is licensed under the Creative Commons Attribution License. 
was physically impressive', whereas he himself was 'rather small and fragile'. Robert is afraid of this man and only loses his fear when he is 36 and meets him again. Robert oscillates between the sentiment of having been the victim of this man and the feeling of guilt for having attracted him, a culpability reinforced by the experience that the abuse stops when Robert deliberately makes himself unattractive. Following the abuse, Robert has known extended periods of alcoholism and addiction to drugs, and he has participated in several spiritual movements and therapeutic groups.

Robert experienced a difficult relationship with God and the church, marked by rejection. Two of these events, at ages 29 and 38, are (inaccurately) described by Robert as excommunications. One priest denies him communion and tells him to come and listen to his sermons, the second says he should redo his sacraments (an obscure phrase when understood literally). Robert also speaks of an intensification of his faith at age 30. His formulations suggest that his relations with God and the church were more determined by his homosexuality than by his victimisation: 'When I was an adolescent, God rejected me for being gay.' At the time of the interview, Robert lived in a religious guesthouse and he had befriended another cleric who turned out to be very accepting. He prayed every day, practiced meditation, and read spiritual literature. Sometimes he took Holy Communion. Although Robert still mistrusted priests in general, they remained in his view the representatives of God, and he regarded the church as the way to God.

\section{Reading stories}

Narrative analysis takes its starting point from the notion that the construction of meaning takes place in the form of stories and story-like fragments. These stories reflect - and arise from - a specific context and history, and they are directed toward another specific context and audience. That means that we have three dimensions of meaning that we can address: the prefiguration or the world behind the text, the configuration or the world within the text, and the refiguration or the world before the text (Ricoeur 1983-1985). Prefiguration analysis focuses on the 'historical' or biographical facts and treats the story as reference to these facts. Configuration analysis focuses on the aesthetic dimension of the narrative and takes the story as a construction of meaning, relatively detached from both facts and audience. Refiguration analysis finally focuses on the performative dimension by investigating the response that is evoked from the audience and the ways in which the narrator substantiates his or her story to meet the criteria of the audience. In this article we will devote most of our attention to the configuration, but we will also discuss some elements of the prefiguration and refiguration, especially when we connect the narrative analysis to the additional information we encountered.

The model for our narrative analysis is based on literary and psychological theories (Ganzevoort 1998). It describes six formal dimensions of narrative that can be operationalised for particular research projects. The first four dimensions pertain to the text or the 'told story', in which the configuration is central: structure, perspective, tone and roles. The last two (positioning and audience) relate to the process of telling, which focuses on refiguration, but also hints at questions of prefiguration.

Structure refers to the use of time and place to order events into a meaningful whole. The connections between the events may be causal, teleological, coincidental, contradictory and so on. Metaphors and linguistic-metaphorical language may also serve to create connections. The narrator tries to organise his material in such a way that it 'makes sense'. This can mean that the interpretations of the elements need to be altered. One aspect of this dimension is the narrative and/or historical chronology. For example, Robert's construction raises questions about the sequence of events: did his conversion take place before or after his first 'excommunication'?

Perspective regards the authorship of the narrator. It tackles the question of the extent to which Robert is able to operate as an 'authoritative' speaker in his own story, and to what degree his story is defined by introjections from other speakers. Perspective also refers to the degree to which a person is able to perceive the perspective of others. It is the 'horizon' of the text. One example of an introjection is probably the rejection by God that Robert perceives in his adolescence, because of his sexuality: 'When I was an adolescent, God rejected me for being gay.' Another is the religious language that he seems to have borrowed to account for his actual beliefs.

Tone refers to the emotional pitch with which the story is constructed, related to genre (tragic, romantic, epic and so on) and style. Although in this interview we only have a transcript of the spoken words and lack information on the emotional dimension, we can note that Robert is nervous in the beginning and more relaxed later on. The dimension of tone addresses emotions in a dialectical way: they are seen as a result of attributed meanings and at the same time as semi-autonomous data that require interpretation. Likewise, the body serves as site and sign of meanings. Put differently: body and emotions are both the material for the narrative and its enactment. Robert's body is a good example. He blames his beauty for attracting the abuse, and he then chooses to debeautify it to enact the meanings of shame and rejection and to discourage the abuser: 'I was guilty because of my beauty. I have attracted that kind of person.' And: 'At sixteen, I stopped washing myself. I stopped shaving. I didn't want to be attractive anymore. And he let me go.'

The dimension of roles denotes the dramaturgical way in which the various characters are located in the story, to set the scene for the story the narrator is constructing. It is the interplay of roles that defines a person's identity, not the protagonist's role in itself. The way Robert describes his parents, for example, tells as much about him and his narrative as the way he describes himself. Whether or not his parents actually fit his description is a question of reference (prefiguration), but that does not define their role in the configuration. The question arising here is how Robert narrates about the relationships with other people (and possibly with God). 
Next to these four dimensions of the configuration, relational positioning is the first (performative) dimension of the refiguration. It relates to the ways in which the narrator is using his or her story to start, maintain, change, or end the relationship with the listener (Day 1993). In this case, it has to do with what Robert wants to elicit from the interviewer. It seems that Robert wants to be acknowledged by the interviewer as an able person (perhaps invoking traditional norms of masculinity) and not merely as a victim. 'You told me what kind of research you are doing and I find that important. I want to participate for the advancement of science.' More implicitly, absent or even imagined listeners may be involved. This raises the question of what he wants to accomplish with the interviewer.

The last dimension relates to the justification by the narrator of his or her constructions. Referring to common knowledge and other authoritative sources, as Robert does with Francis of Assisi, the narrator may try to convince the audience that his or her story is a legitimate and plausible one. In Robert's case, his statement that he knew he was gay long before the abuse may serve to justify his homosexuality to the interviewer, who otherwise might think that his homosexuality was caused by the abuse.

Within this framework of formal dimensions, we perform a more thematic analysis. For that purpose we take our starting point in the opening sequence. We expect to find the basic themes of any interview in the linguistic structure of the opening sequence. Obviously, the content of these fragments may be coincidental or invited by the interviewer, but even then the specific ways in which the interviewee formulates his or her answers is indicative of the kind of discourses the person employs. The initial themes derived from this opening should be checked against the whole interview to search for a 'best fit'. In Robert's story, three themes can be observed in this opening sequence: talking, emotion and agency:

'I feel a little bit nervous. I haven't spoken about it very often. I am eager to begin and to see whether I can continue. Because I trust you. You told me what kind of research you are doing and I find that important. I want to participate for the advancement of science. Understand what it does to people and find means of prevention.'

Firstly, talking appears right at the beginning. Even before these first full lines, Robert thanks the interviewer for telling him what is going to happen during the interview. Talking serves to clarify situations and to make them safe. Robert proceeds on this theme by saying: 'I haven't spoken about it very often.' Later on he will add: 'Silence harms people who are victims. We need to talk.' That shows that sexual abuse is still more or less a secret topic. His evading formulation suggests that he is not used to putting it into words. It may also be that the topic he wants to talk about is not precisely what the interview setting would suggest. This raises the analytical question of understanding what it is Robert will be talking about, and whether he has a language to do so.

Secondly, Robert highlights his emotional state. 'I feel a little bit nervous.' This has to do with his uncertainty whether he will be able to perform well in the interview. Apparently, his own capability is at stake and not his trust in the interviewer: 'Because I trust you.' Robert's formulations indicate that passion or emotion may be important. The basic emotions expressed in this sequence have to do with uncertainty and trust. A fundamental question for the analysis may be what emotions figure in his coping with the situation, and which emotions are allowed a place in the narrative and which are not.

Thirdly, Robert works with the notion of action or agency. 'I am eager to begin and to see whether I can continue.' Robert is not sure that he can talk about it and he even expresses some anxiety in this regard. In view of his capability, he focuses on the positive contribution he may present to the advancement of science and the prevention of sexual abuse. The verbs 'begin' and 'can' focus on his active role in the process. It is nevertheless interesting that his motivation lies in what he might contribute to the well-being of others, not in what it might mean to himself. Whether that is a positive sign of altruism or a negative form of not attending to his own needs, is an interesting question for the analysis. In a clinical situation, the pastoral counsellor or psychotherapist might follow up on these observations.

These three themes will be complemented by two issues of content emerging from the project's research question: Robert's conflation of sexual abuse and homosexuality in his story and his religious language. We will therefore analyse these five themes in our analysis: talking, emotion, agency, sexual identity and religious language (God-talk).

\section{Talking}

Not untypical for survivors of sexual abuse, the theme of talking runs throughout the interview to describe a sense of isolation in Robert's life. Right from the start, Robert makes it clear that he has not spoken much about 'it', although he says that his parents are open-minded and have a mentality of 'live and let live'. However, it seems as if this openness may be somewhat superficial, or wished for, and that real issues are not addressed in family communication. At home they do not talk about religion. Robert's homosexuality and sexual abuse have not been talked about either - at least not for a very long time - and it is not clear whether he can presently discuss it with his parents. Even if that is the case, it is interesting to note that Robert does not tell the interviewer about such a conversation.

The sexual abuse was something Robert could not discuss with anyone. His parents seemed unavailable, or might even prove judgmental considering his use of alcohol and his homosexuality (Robert says he had no confidante during childhood), so that Robert remained in solitude. From these experiences, Robert claims that silence harms the victims. He keeps silent about the abuse until he is 29 and then speaks to a priest. When Robert is 36 , the perpetrator invites him for a meeting and asks for forgiveness, which Robert says he quickly gave him as he was no longer afraid - a sign of 
agency. At a next meeting, Robert ignores him and does not want to talk himself: that story is over and the book is closed. However, Robert sounds as if he had built up an emotional wall to protect himself.

Robert also describes talking relationships with religious figures of authority. The sisters and the chaplain at school are not described as partners in conversation, but they are nevertheless present and he pictures them as warm and gentle. The two priests in whom he confides later on (when he is 29 and 38 respectively) disappoint him deeply. Instead of understanding and encouraging him, at least in his religious quest, these priests sent him away. What is unclear in these relationships is what exactly Robert told them. He says he told them everything, and within the context they probably focused on his homosexuality. The break-up of his gay relationship was the direct reason for his confiding in the second priest. Another indication is the choice of words when he refers to his priest-friend who does not judge him, so that he can 'say everything'. He adds that he does not tell people in the congregation that he is gay because they wouldn't understand. All this suggests that in his conversations with the priests, his story is framed as one of homosexuality, not of sexual abuse. That may indicate that he expects his audience to read his story as such. Conversely, this research interview on sexual abuse and spirituality might have been his first chance to tell it in a different way.

In Robert's longing for God, the church and its authority figures are seen as important mediators. When asked why he confided in a priest, Robert answers: 'It is the representative of God on earth. I wanted to come closer to God.' The way to God appears to be through the church and through the priest. Later on, his 'starting anew' is also framed religiously, almost as a conversion. Despite his negative experiences, he wanted to give the church a second chance. The message that Robert wants to convey to the church has to do with talking as well. He points out the 'closed minds' of some priests that frightened him and others. Silence hurts the victims, he states, and it is important that talking is supported.

Finally, it is clear that for Robert, praying is somehow related to talking. As a child he learns the customary prayers, and he continues saying them as an adult (at least in frequency, if not in form). Besides that, he develops a spiritual life including meditation and other behaviours. Later on, his prayers become requests for help, strength and courage. There is no real expression of his emotions in his prayers, except that when asked about his feelings towards God, he says that he has been screaming in the forest and vomiting his rage.

\section{Emotion}

One of the most interesting emotions in Robert's story is anger, expressed at three points in the interview. Firstly, it is one of his sensations at the time of the abuse, but it is unclear whether he directs this anger toward himself, his abuser, or someone else. In fact, when he meets his abuser 10 years later, he says that he has overcome his emotion of fear, rather than of guilt, shame or anger. It is therefore questionable which emotion was central in Robert's experience of his abuser and in the narrative reconstruction that ensued. It is quite likely that he experienced a whole series of emotions toward his abuser, but in his narrative construction, anger is not dealt with properly. Secondly, Robert describes how he expressed his anger: 'I have been screaming in the forest. I have vomited my rage.' Interestingly, these words come in response to a question about his feelings towards God. Apparently his anger was directed toward God.

All this makes the third instance of anger very interesting. When Robert shares that he prays to become an instrument of peace, it seems out of place in the particular discourse he is engaged in at that moment. His language there is about care and helpfulness, and it would have been more appropriate to pray to become an instrument of healing or something like that. Asked about his mission in life, Robert says:

'To do my best. To help others. I'd like to open a therapy centre for gay people. To be useful. There is a lot to do. To give a message somehow like the prayer of Saint Francis: Lord make me an instrument of peace.'

Peace is the opposite of war or conflict, in this case notably inner war and conflict, and thus anger. In an indirect way, Robert discloses the role of anger in his story.

\section{Agency}

The third topic is agency. Again, this is a common issue for survivors of sexual abuse. It takes on specific forms for male survivors through its direct connection to masculinity; in many cultural settings masculinity implies agency, especially in sexual matters. The passive, 'receiving' role is traditionally seen as a denial of masculinity. Moreover, it is part of the ideology of masculinity that men have a constant urge for sexual activity and that it has little emotional meaning for them. Victimisation is therefore a fundamental threat to masculinity, because it carries the notion that there was sexual activity that was unwanted and that it has a profound emotional meaning (Dorais 1997). If this picture fits the case of Robert, the question is how he resolves this threat in his narrative.

One indication of this theme of agency and masculinity lies in the description of the abuse. He pictures his abuser as a strong big man, whilst stressing that he himself is physically small and fragile. One of his responses is therefore to start sports activities to develop his muscles and achieve a more masculine image. In that sense, he tries to become as masculine as his abuser, who was very masculine and active in sports. A typical masculine element in the abuse narrative is the fact that it occurs in a work setting.

Robert's response is very complex. He speaks of guilt for enjoying the sexual activity. Probably this is connected to the issue of homosexuality, because the abuse appears to have been his first experience of actually engaging in same-sex activity. At this point he had already known for 2 years that 
he was gay - as he tells the story. It is therefore possible that he had experimented sexually with other boys, but he does not say anything about such experiences. Given his demographic context and the religious values of his parents, we can conjecture that they would not easily accept their son's homosexuality. The loneliness that this may have caused (Robert tells of an overworked father and an overprotecting mother) made him more vulnerable to the attention of a charming, social, sportive, charismatic, masculine man. Robert stays clear of describing it as a teenage homosexual crush for this man, but he does highlight his enjoyment and the confusion that follows. This is not uncommon for victims of abuse, often evoked by the sexual response of their own body which seems to 'conspire' with the abuser. Robert symbolises this loss of agency with his image of the puppet on a string, associated with inferiority: 'Anger, shame, pain, inferiority. I became a puppet. I had trouble finding myself back. I lost confidence in myself.'

Robert's guilt, however, is not only linked to his enjoyment. He is also guilty because he attracted the abuser by his beauty. This again is rather complex. It indicates that Robert identifies with the more feminine role which is traditionally shaped as being looked at rather than looking at others (Bordo 1999). In this role, he feels guilty, which paradoxically implies that he attributes some agency to himself, albeit in the role of the seducer. The rationale behind it is that guilt implies agency and therefore puts an end to the feelings of powerlessness. In a way, one might be better off being guilty and therefore powerful, than without guilt and therefore weak. As a guilty person, Robert feels able to change the situation, at least in his own perception. If he acted differently, the abuse would end. The powerless person, in comparison, has no way of changing the situation, which means that the abuse can continue indefinitely. Unfortunately, this understandable but in the long run dysfunctional perception is reinforced when Robert decides to create an unattractive appearance at age 16. This strategy has the desired effect and the relationship ends there, but it strengthens the idea that the whole abuse was his own fault after all. Agency here is then loaded negatively through its connection with guilt. In Robert's religious narrative, his guilt puts him at the mercy of God, which potentially undermines his agency. This is certainly true during his childhood and adolescence when he saw God as 'a punishing God. In school we learned about hell, sin, evil. Everything was black or white. Those who sinned don't go to heaven'. As an adult, he transforms this image into one of: 'A God of love. He accepts me. He does not judge me. The supreme Being. I have a place in heaven despite all.' Agency remains an issue. When the perpetrator later asks for forgiveness, Robert responds that he 'functions well' and that he is 'not afraid anymore'. It is almost as if Robert denies the abuser's agency. Although he consents to the term 'forgive', Robert does not blame the abuser, but mainly himself.

The issue of agency reoccurs in Robert's wish to be meaningful in his work for others. He tried to do that in his work in victim care, but found himself unable to carry the burden of others. In effect, this even made him relapse in his addictions, which can be considered as losing the battle of his life and reinstating his guilt. His motive for participation in the present research was also framed as a way of being helpful to other gay people and of working at the prevention of sexual abuse. This need to be effective is also framed religiously: 'God needs me and I need God. He gave me a mission.' This can be read as a narrative of the religious restoration of power, agency, masculinity and spiritual well-being, raising crucial questions about the spiritual and theological complexities of power (Ganzevoort 2000; Poling 1991). Robert's narrative also speaks a lot about the emotion of shame, which is conceptually connected to hiding one's face and to the fear of being exposed (Pattison 2000). This exposure can be related to the abuse, but it is probably more about his homosexuality and his role in the abusive relationship. It is directly connected to the impossibility of talking.

\section{Sexual identity}

Although the research project focused on the interplay of sexual abuse and religion, homosexuality seems to be the most important topic in Robert's story - which is not uncommon for male victims of sexual abuse, especially when the abuser is male as well (Gilgun \& Reiser 1990). The coincidence of sexual abuse and homosexuality challenges the person to develop a narrative that makes sense of both, especially in a culture where debates about religion and homosexuality are prominent and full of conflict. Robert then has to account for the interplay in his story.

One option would be to explain the person's homosexuality based on the abuse. There is some research that seems to suggest that a homosexual orientation may be caused or strengthened by abusive experiences (Cameron \& Cameron 1995). Usually this is interpreted in a learning model of behaviour, or in a psychodynamic model according to which the victim identifies with the perpetrator and wants to be like him. In some evangelical models of 'gay ministry', homosexuality is explained as a dysfunctional search for restoring the masculinity that was threatened by the abuse. Robert, however, clearly refuses this interpretation by stating that he knew he was gay 2 years before the abuse: 'I am gay. I knew before this happened. I have known since I was eleven. My parents didn't know. I had no one to talk to.' This is consonant to the usual 'gay' view that homosexuality is innate, which is equally essentialist in that it grounds identity in biological nature. Of course, the 'evangelical' case could be furthered in his story by applying the outdated psychodynamic interpretation that an overprotective mother and absent father would not give the boy enough opportunity of freeing himself from the obsessive symbiosis with the (archetypical) mother, so that instead of becoming a man like his father he would develop a more feminine identity. But although the ingredients of such a view could be taken from his story, Robert clearly denounces it, possibly because it would undermine his self-acceptance as a gay person.

A second option would be to explain the abuse based on his homosexuality. A traditional view in this regard is to suggest that homosexuals are persons with a certain type of 
body and character, which makes them more feminine and therefore more vulnerable to abuse. This view runs the risk of stereotyping and stigmatising homosexuals and of blaming the victim, as Robert seems to do himself. A more critical version holds that the vulnerability is a result of the nonaccepting context of the child that is experiencing himself to be(come) homosexual. As we have shown earlier, it makes sense to read Robert's narrative as supporting this idea. That is precisely part of the reason why he feels guilty and why he is unable to seek the support that he needs. The rejection of his homosexuality is found not only in his parents, and later on with the clergy, but in his adolescence already, in how he views God. According to Robert, God rejected him because he was gay. The absence of God, and maybe the abuse itself, appears to be interpreted as punishment for his homosexuality. This corresponds to the punitive God that Robert refers to later on and that he locates in his childhood:

'As a child I saw Him as a punishing God. In school we learned about hell, sin, evil. Everything was black or white. Those who sinned don't go to heaven.'

Now that Robert has found a more accepting context, it is also possible for him to experience God as less judgmental regarding his homosexuality.

In accepting his homosexuality, Robert has to make sense of his experiences of sexual abuse. He does this firstly by casting doubt on his abuser's motives, claiming that his marriage was insincere: 'I later knew that it was to hide his habits.' He seems to suggest that his abuser's desires may have had more to do with power or perhaps paedophilia: 'He killed the child in me.' However, Robert does not describe the perpetrator as homosexual but instead focuses on the difference in power. At the same time he claims that his homosexuality predated the abuse. The connection with his own desires is ambiguous, however: his confusion stems from the fact that he both enjoyed and disliked it. Robert's confusion about the abusive relationship further complicated the already difficult integration of his sexuality. In that sense his parents, the clergy and his abuser contributed to a highly problematic development of his sexual identity. The key issue in Robert's story seems to be the depersonalisation in which he was no longer author of his own sexual narrative, and in which the narrative that was forced upon him had no understanding from his audience.

\section{God-talk}

The final topic to address here is the God-talk in Robert's story. This regards his God-images and his view of how God acts (or rather does not act) in this world. We use the phrase 'Godtalk' because it helps us focus on the linguistic dimension rather than on content only. The issue was already present in previous sections, revealing the interrelations between his religious, emotional, social and sexual narratives.

As mentioned, in his childhood Robert saw God as punitive, waiting to send a person to hell if they committed a sin. This obviously became a very serious issue for Robert given his homosexuality. In his adolescence, he therefore distances himself from God, and he feels that God has also distanced himself. 'God wasn't present in my life.' When he is 29 , he wants to come closer to God again, and therefore goes to the priest, only to be disappointed. Following this disappointment, things seem to go downhill: 'Nothing went right.' At rock bottom, Robert starts praying, asking God to help him and provide strength and courage to go through. In this prayer, God does not take over Robert's agency but rather supports it. Later on, following the break-up of a relationship, he again seeks contact with a priest and is disappointed once more.

When he describes his present relationship with God, he focuses on love and proximity:

'A God of love. He accepts me. He does not judge me. The supreme Being. I have a place in heaven despite all. The great Watchmaker who sees everything. I have understood that God is evolutionary and so am I. He changes and I change. He needs me and I need Him.'

The language here is fragmentary, and the images seem poorly integrated with one another. The watchmaker is traditionally a metaphor of distance; the evolutionary God of process theology is not usually connected to the traditional images of being accepted into heaven; the all-seeing God is often seen as punitive rather than accepting; the collaborative God-image is somewhat at odds with the notion of a supreme being. If Robert speaks like this, it seems he has collected some religious views (partly from his therapy groups, partly from the bookshelves in a religious guesthouse where he stayed) that he can resort to every now and then, without developing them into a coherent religious narrative. The expressions still portray implicit guilt: 'despite all ... He does not judge me', but the central tenet is much more positive. What these three notions contribute is a combination of unconditional acceptance and encouragement to take responsibility. In that sense, they support him in developing the kind of identity that he needs as an adult. According to Robert's theological narrative, God will not act directly and an intimate experience of the relationship with God is not to be expected. It is in terms of vocation that God is present in his life, supporting his agency rather than his dependency.

However, the narrative conflict about his relationship with God still looks unresolved as his actual God-talk sounds like the exact opposite of the God-image of his childhood, like an avatar of the black and white religious world he criticises. Robert's present religious perspective offers the flip side of his childhood narrative, but it is not an integrated story. In fact, Robert makes a strict distinction between his religion and his faith: 'My religion has put a spoke in the wheels, but my faith has guided me to become what I am today.' At the same time, his faith is clearly influenced by his religious tradition. He also keeps trying to connect to a church, even if that means that he cannot develop a fully open gay identity. The tension remains, and Robert's narrative shows signs of a 'commuting identity', combining fragmentary elements from conflicting life views rather than integrating them (Ganzevoort, Van der Laan \& Olsman 2011). 


\section{Beyond narrative: Some further facts of Robert's life}

The narrative analysis of Robert's story offers a unique insight into the complex ways in which he has construed the meaning of his experiences. It sheds new light on the transformations of his understanding and God-talk, the complicated development of his sexual identity and the lack of integration between the various aspects of his narrative.

But narrative is not everything, as we were to find out some time after the interview. Follow-up communication in the community setting in which Robert participated revealed new information that Robert had not included in his narrative. This information challenges his narrative and at the same time deepens our understanding of his troubled efforts to develop and live a meaningful narrative.

This new information posed an ethical conundrum for the researchers. Robert had signed his consent to the interview and his participation in the research project. He had not explicitly consented to using this new information. The new information, on the other hand, was more publicly available in the ongoing community relationships and was in part disclosed by Robert himself. Obviously, the interpretation of the narrative would not be complete and/or valid if we left out the additional information. At the same time we could not simply stretch his consent to include this wider narrative. This is all the more important given the sensitive fact of his suicide. We have for that reason decided to treat it as a case study using this semi-public information together with his personal story for which he did give consent. It seems to us that reporting some of these facts opens a significant door to Robert's inner spiritual struggle. 'Silence harms people,' said he. Obviously we exerted more than usual caution in protecting anonymity.

Between the time of the interview and the moment of his death, several facts surfaced. Firstly, Robert had a history of sexual relationships with priests prior to the interview. Secondly, some time after the interview, Robert ran into trouble and his life went downhill as he faced allegations of sexually approaching a minor. Whilst awaiting his trial, Robert committed suicide. His body was found on the floor of a crack house, amidst pictures of little boys, pills, empty containers and bottles. He was buried with a brief civil funeral without a religious ceremony.

There are clear gaps between these surfacing facts and the narrative Robert had shared with us. These gaps make it all the more interesting to read how Robert describes his motivation to participate, both in opening and closing the interview: 'I want to participate in the advancement of science. Understand what it does to people and find means of prevention.' He closes by saying:

'But the important thing is to work on prevention. To find ways to prevent this from happening to others. Research is one of these prevention tools. I'll look for more tools.'
Seen in the light of the unfolding case study, this redundancy may refer to both his experiences of childhood sexual abuse and to the battle Robert fought within himself. In hindsight, his comments during the interview may have been a call for support to prevent himself from unwanted actions, but the interview setting somehow did not evoke such a critical hermeneutic.

In our interpretation, his homosexuality seemed to be at the heart of Robert's religious and social drama as it appears in his narrative. This becomes all the more poignant when we connect this to his sexual relations with a priest on more than one occasion. His experience with priests was obviously even more complex than he already described in his narrative, now including the role of a sexual partner. Their interventions hovered between homosexual relationships and what he perceived as excommunication, and the hearty welcome at the religious guesthouse from a generous priest that did not suspect anything. Inasmuch as Robert considered the priests as God's representatives, we can believe that their influence was rather harmful, particularly in the light of the fact that the priest whom Robert presented as a friend who did not judge him, and to whom he could tell everything, was actually having an affair with him. Although we have no knowledge of how Robert interpreted this sexual relationship, it would probably count as clergy sexual misconduct because of the pastoral relationship they were in. At any rate, the combination of a sexual relationship with a priest who at the same time represented a church that condemns homosexual behaviour must have been highly confusing. This sheds new light on his words: 'I am still afraid of priests today.'

Finally, the unfolding case brings us back to the issues of shame, silence and the fear of being exposed. It looks like Robert was not the only one in his family to bear such a burden. His family, regular churchgoers, opted not to offer him a church funeral to avoid flaunting Robert's secrets. Contrary to his desperate search for a closer connection to God via the Church, his family was opposed to a religious funeral to avoid family shame. Even after his death, Robert remained hidden, silenced. Although Robert described his parents as open-minded, adding that they educated their children in an attitude of live and let live, silence and secrecy followed his death just as they had troubled him during his life.

The information that surfaced after the interview and until his death underscores several aspects of our narrative analysis. It clearly demonstrates the emotional troubles Robert went through and the narrative tensions that he was experiencing. At the same time it challenges us as narrative researchers to deepen our critical hermeneutical perspective in working with autobiographical narratives. This does not mean that we deny the credibility of the stories, but that we understand them as narrative performances in which the narrator renders an account of his or her life before a specific audience. Understanding the gaps between story and external reality makes us only more aware and appreciative of the narrative efforts and achievements of Robert. After all, he did 
try hard to offer a meaningful narrative in the turmoil of his troubled life and to save his relationship with God.

\section{Conclusion}

In this article we have sought to contribute to the understanding of the narrative efforts of male victims of sexual abuse. Robert's narrative was our guide here as we analysed issues emerging from it like talking, agency, emotions, sexual identity and God-talk, issues that are not confined to Robert's story but concern most sexually abused males. The gap between the autobiographical narrative he offered during the interview and additional information surfacing in the time after the interview allows for a critical understanding of the narrative process.

\section{Acknowledgements Competing interests}

The authors declare that they have no financial or personal relationship(s) that may have inappropriately influenced them in writing this article.

\section{Authors' contributions}

J.-G.N. (Université de Montréal) was project leader of the original research, R.R.G. (VU University Amsterdam) performed the main narrative analysis and wrote the first draft of the article.

\section{References}

Bordo, S., 1999, The male body. A new look at men in public and in private, Farrar, Straus and Giroux, New York.

Cameron, P. \& Cameron, K., 1995, 'Does incest cause homosexuality?', Psychological Reports, 76, 611-621. http://dx.doi.org/10.2466/pr0.1995.76.2.611, PMid:7667476

Day, J.M., 1993, 'Speaking of belief. Language, performance, and narrative in the psychology of religion', International Journal for the Psychology of Religion 3(4), 213-229. http://dx.doi.org/10.1207/s15327582ijpr0304_1

Dorais, M., 1997, Ça arrice aussi aux garçons. L'abus sexual au masculin [It also happens to boys. Male sexual abuse], Typo, Montreal.

Ganzevoort, R.R., 1998, 'Reading by the lines. Proposal for a narrative analytical technique in empirical theology', Journal of Empirical Theology 11(2), 23-40. http://dx.doi. org $/ 10.1163 / 157092598 \times 00112$

Ganzevoort, R.R., 2000, 'La dynamique du pouvoir entre violence et justice. Réflexions de théologie pratique' [The dynamic of power between violence and justice. Practical Theological Reflections], Théologiques 8(2), 15-32. http://dx.doi.org/10.7202/ 005007ar

Ganzevoort, R.R., 2002, 'Common themes and structures in male victims' stories of religion and sexual abuse', Mental Health, Religion \& Culture 5(3), 313-325. http:// dx.doi.org/10.1080/13674670210130045

Ganzevoort, R.R., 2006, 'Masculinity and post-traumatic spirituality', paper presented at the international colloquium on Christian religious education in coping with sexual abuse, Montreal, 25-26th May.

Ganzevoort, R.R., Van der Laan, M. \& Olsman, E., 2011, ‘Growing up gay and religious. Conflict, dialogue, and religious identity strategies', Mental Health, Religion \& Culture Conflict, dialogue, and religious identity strategies', Mental Health, Re
14(3), 209-222. http://dx.doi.org/10.1080/13674670903452132

Gilgun, J.F. \& Reiser, E., 1990, 'Sexual identity development among men sexually abused in childhood', Families in Society 71, 515-523.

Mendel, M.P., 1995, The male survivor. The impact of sexual abuse, Sage, Thousand Oaks.

Nadeau, J.-G., Golding, C. \& Rochon, C., 2012, Autrement que Victimes. Dieu, enfer et résistance chez les victimes d'abus sexuels [Other than victims. God, hell and resistance among victims of sexual abuse], Novalis, Montreal.

Pattison, S., 2000, Shame. Theory, therapy, theology, Cambridge University Press, Cambridge. http://dx.doi.org/10.1017/CBO9780511612411

Poling, J.N., 1991, The abuse of power. A theological problem, Abingdon, Nashville.

Ricoeur, P., 1983-1985, Temps et récit [Time and Narrative], Editions du Seuil, Paris. 